African Crop Science Journal by African Crop Science Society is licensed under a Creative Commons Attribution 3.0 Uganda License. Based on a work at www.ajol.info/ and www.bioline.org.br/cs DOI: https://dx.doi.org/10.4314/acsj.v27i1.1

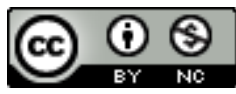

\title{
FUNGI ASSOCIATED WITH A DRY INVASIVE WHITE PATCHES ON TRUNKS OF ECONOMIC FRUIT TREES IN SOUTH-WEST NIGERIA
}

\author{
S.B. AKINDE, W.A. LAMIDI ${ }^{1}$ and M.T. AYENI ${ }^{1}$ \\ Department of Microbiology, Faculty of Basic and Applied Sciences, Osun State University, \\ P.M.B. 4494, Osogbo, Nigeria \\ ${ }^{1}$ Department of Agronomy, College of Agriculture, Ejigbo Campus, Osun State University, \\ P.M.B 4494, Osogbo, Nigeria \\ Corresponding author: wasiu.agunbiade@ uniosun.edu.ng
}

(Received 12 November, 2017; accepted 19 November, 2018)

\begin{abstract}
An unprecedented number of fungal and fungal-like diseases are the main threat to the diversity and productivity of economic fruit trees in south-west Nigeria. The objective of this study was to investigate the fungi associated with dry invasive whitish patches, noticeable on trunks and branches of cocoa (Theobroma cacao), kola-nut (Cola spp.) and sweet orange (Citrus sinensis) trees prevalent in southwest Nigeria. A total of 108 whitish patch scraped samples were aseptically obtained from the affected cocoa, kola-nut and sweet orange trees in Osogbo, Ife, Ejigbo and Ilesha plantations in south-west Nigeria for this study. Viable fungal populations, were determined using the spread-plate techniques; and pure fungal isolates were identified through their morphological appearance, microscopic features and sporing structures. Mean viable fungal count in the samples ranged from $3.85 \times 10^{4} \pm 0.00$ to 9.75 $\times 10^{3} \pm 0.00 \mathrm{CFU} \mathrm{g}{ }^{-1}$. Viable fungal counts were significantly different $(\mathrm{P}<0.05)$ between fruit tree species and across locations. A total of 52 fungal species belonging to 21 genera were isolated, with Aspergillus and Penicilliumas predominating and occurring at 23 and 17\%, respectively. Other isolated genera included seven from cocoa trees; ten from kola-nut trees and five from sweet orange trees. There is need for appropriate control strategies to prevent further spread in contiguous plantations.
\end{abstract}

Key Words: Aspergillus, kola-nut, sweet orange, Theobroma cacao

\section{RÉSUMÉ}

Un nombre sans précèdent de champignons et de maladies fongiques sont les menaces principales à la diversité et à la productivité des fruitiers à valeur économique dans le sud-ouest du Nigéria. L'objectif de cette étude était d'investiguer les champignons associés aux taches invasives sèches blanchâtres, visibles sur les troncs et les branches du cacaoyer (Theobroma cacao), colatiers (Cola spp.) et l'oranger sucré (Citrus sinensis) prévalent dans le sud-Ouest du Nigéria. Un total de 108 échantillons de taches blanchâtres raclées a été aseptiquement obtenues des pieds de cacaoyer, colatier et oranger sucré dans les plantations de Osogbo, Ife, Ejigbo et Ilesha dans le sud-Ouest du Nigéria pour cette 
étude. Des populations viables de champignons, ont été déterminées en utilisant les techniques de plaque de diffusion; et des isolats purs de champignons ont été obtenus à travers leur apparence morphologique, les caractéristiques microscopiques et les structures de production des spores. Le nombre moyen de champignon dans les échantillons variait de 3,85 x 104 $\pm 0,00$ au 9,75 x $103 \pm 0,00 \mathrm{CFU}$ $\mathrm{g}^{-1}$. Les nombres de champignons viables ont été significativement différents $(\mathrm{P}<0,05)$ parmi les espèces fruitières et à travers les localités. Un total de 52 espèces de champignons appartenant à 21 genres ont été isolées, avec Aspergillus et Penicilliumas les plus prédominants et apparaissant à 23 et $17 \%$, respectivement. Autres genres d'isolats comprennent sept de cacaoyers, dix des colatiers et cinq des orangers sucrés. Il y a nécessité de détermines des stratégies appropriées de contrôle pour prévenir la propagation avancée dans les plantations contiguës.

Mots Clés: Aspergillus, colatier, orange sucrée, Theobroma cacao

\section{INTRODUCTION}

Cocoa (Theobroma cacao), kola-nut (Cola spp.) and sweet orange (Citrus sinensis) are important economic cash crops in tropical Africa. Cocoa serves as raw material source for local confectionery, beverage and winery industries in African countries (Adejumo, 2005; Verter and Beèváøová, 2014; 2016). Kola-nut and citrus, on the other hand, are widely cultivated for their euphoriant value, bioactive compounds and pharmacological properties with strong social and traditional significance (Oboh et al., 2014a; 2014b; Fallico et al., 2017).

South-west Nigeria is the country's main growing region of cocoa, kola-nut and sweet orange trees. The cocoa, kola-nut and sweet orange trees in this region are prone to severe drought, pests and microbial attacks, contributing to low fruit yield (Adejumo, 2005; Asogwa et al., 2011). The susceptibility of these important wood plants is further exacerbated by reliance on seedlings from the wild (Bailey et al., 2016; Surujdeo-Maharaj et al., 2016). South-west Nigeria, like most of the other African countries involved in largescale cultivation, is yet to benefit from the propagation of improved cash crop seedlings with diseases-prevention potential through genetic modifications and use of relevant biotechnological tools. Furthermore, there have been no contiguous kola-nut and sweet orange plantations in the region; rather they are scattered in cocoa plantations, mixed-crop farmlands and forests (Asogwa et al., 2011).

In south-west Nigeria, an increasingly common disease feature on cocoa, kola-nut and sweet orange trees are whitish patches usually noticeable on the tree trunks and branches (Plate 1). Once established on a tree, the whitish patches spread rapidly in the plantation, mainly on trunks and branches of both young and mature cocoa, kola-nut and sweet orange trees. Farmers in the region obtain very low cocoa fruiting, especially on the parts covered by the whitish patches. Although the observed whitish patches on the tree trunks and branches may be the consequence of syntrophic activity of various plant pathogens, the pattern of spread as well as the dry scaly nature of the disease condition is suggestive of predominant fungal attack.

The objective of this study was to investigate the occurrence and characteristics of fungi that are associated with the whitish patches found on stem and branches of the fruit trees in south-west Nigeria.

\section{MATERIALS AND METHODS}

Site description. This study was conducted in Osun State in south-west Nigeria. Specifically, four sites, namely Osogbo, Ife, Ejigbo and Ilesha were considered for the study. The study sites fall within the tropical rainforest zone of south-west Nigeria, and were characterised by two rainy seasons 


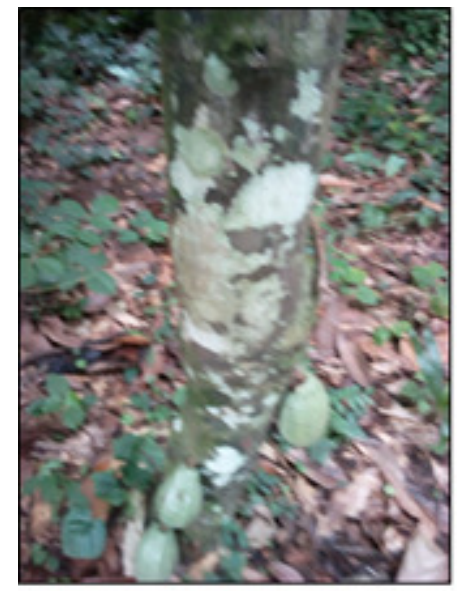

A

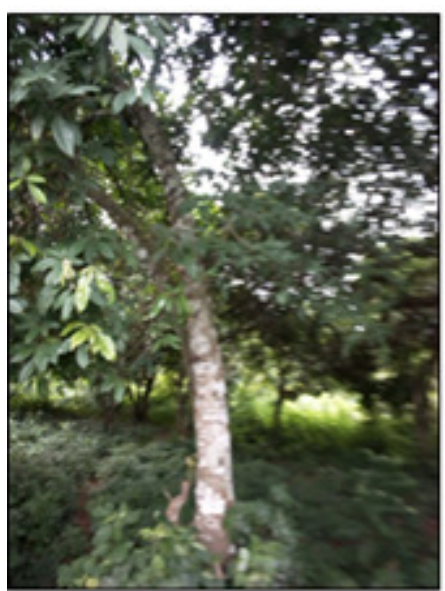

C

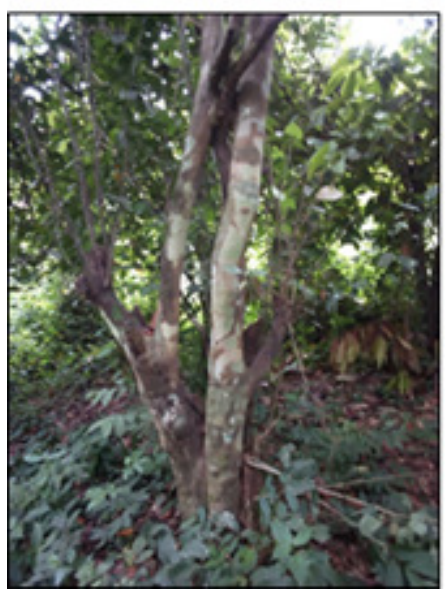

$\mathbf{E}$
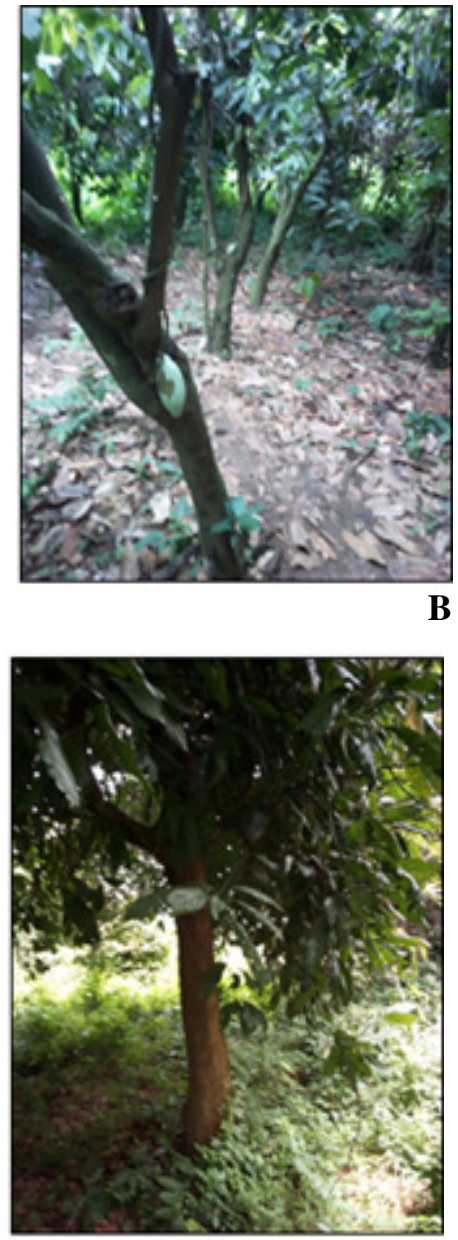

D

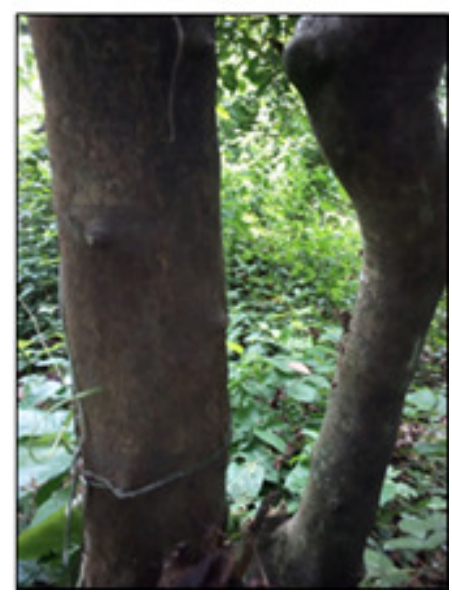

$\mathbf{F}$

Plate 1. Healthy and white patches affected trees. (A) affected cocoa (no pod grows on the affected parts), (B) healthy cocoa, (C) affected kola-nut, (D) healthy kola-nut, (E) affected sweet orange, and (F) healthy sweet orange tree. 
(March - November) and the dry (November - February) seasons. The dry season is also known to bring Harmattan dust.

Collection of samples. Sterilised scalpels were used to scrape the whitish stuff from randomly selected adult ( $>20$ years) tree trunks and branches of cocoa, kola-nut and sweet orange into separate labelled $10 \mathrm{ml}$ sterile screw-capped plastic containers. To eliminate surface contamination of the affected areas, the trunks and branches were surface-sterilised with $0.5 \%$ sodium hypochlorite prior to scraping (Mejía et al., 2014).

A total of 27 samples were obtained per study site in a 3 (different farms) x 3 (kinds of trees) x 3 (replicates) factorial arrangement as analytical study design. Altogether, 108 samples of the whitish patched stuff were obtained from the four selected sites and used for the study. The samples were preserved in ice boxes at $4 \pm 2^{\circ} \mathrm{C}$ and transported to the laboratory for fungal evaluation.

Enumeration of fungi. Fungal isolates were recovered from the whitish patch scrapings on potato dextrose agar (PDA) plates, fortified against bacterial growth with $0.25 \mathrm{~g}$ chloramphenicol. Fungal estimation was carried out by aseptically weighing $1 \mathrm{~g}$ of each sample into $9 \mathrm{ml}$ of Ringer's solution. This was followed by ten-fold serial dilution. A 100 $\mu \mathrm{l}$ aliquot from $10^{1}, 10^{2}, 10^{3}$ and $10^{4}$ of each serially diluted sample were spread-plated onto PDA plates in triplicates.

The inoculated plates were incubated at 25 $\pm 2^{\circ} \mathrm{C}$ for 7 days in a humidified environment. Discrete fungal colonies were counted on each plate and recorded. Counts per gramme of sample were calculated using the formula below and reported as colony forming units (CFU) per gramme (Nwachukwu and Akpata, 2003).

Number of colonies counted x Dilution factor used $\mathrm{CFU} / \mathrm{g}=$

$=$

Volume plated in $\mathrm{ml}$

Equation 1
Pure isolates were then obtained by selecting discrete colonies with distinct morphological differences such as colour, texture, size and shape. They were randomly picked using a mounting needle, and sub-cultured onto fresh PDA plates, and incubated for 5 days. All axenic strains were stored on PDA slants for further characterisation (Akinde et al., 2017).

Identification of fungal isolates. The pure fungal isolates were identified through their morphological appearance, microscopic features and sporing structures (Humber, 1997; Campbell and Johnson, 2013). Morphological characterisation of fungi isolates was based on fungal appearance on surface and reverse side, texture and colour of the colony.

Microscopic identification was by using a sterile inoculating needle, whereby a small portion of fungi isolate was picked and placed in a drop of lactophenol cotton blue stain on a clean grease free microscope slide. A clean cover slip was then gently placed on the prepared slide and examined under a light microscope at X40 magnification. The main characteristics considered for their identification included Hyphae: septate or nonseptate; Mycelium: coloured or non-coloured; Growth: rapid, slow or moderate; and Texture: powdery, woolly, downy, glabrous or velvety.

Statistical analysis. The viable fungal count results were presented using descriptive statistics (tables, figures and plates). Differences between mean values were compared using ANOVA $(\mathrm{P}<0.05)$. Mean separation was done using Least Significant Difference (LSD) at the probability level of 5\%. Statistical analysis was carried out using CoStat, CoHort Software, 2014.

\section{RESULTS}

The typical appearance and distribution of the whitish fungal-like patches on affected cocoa, kola-nut and sweet orange trees are presented in Figure 1. The mean viable fungal count in 


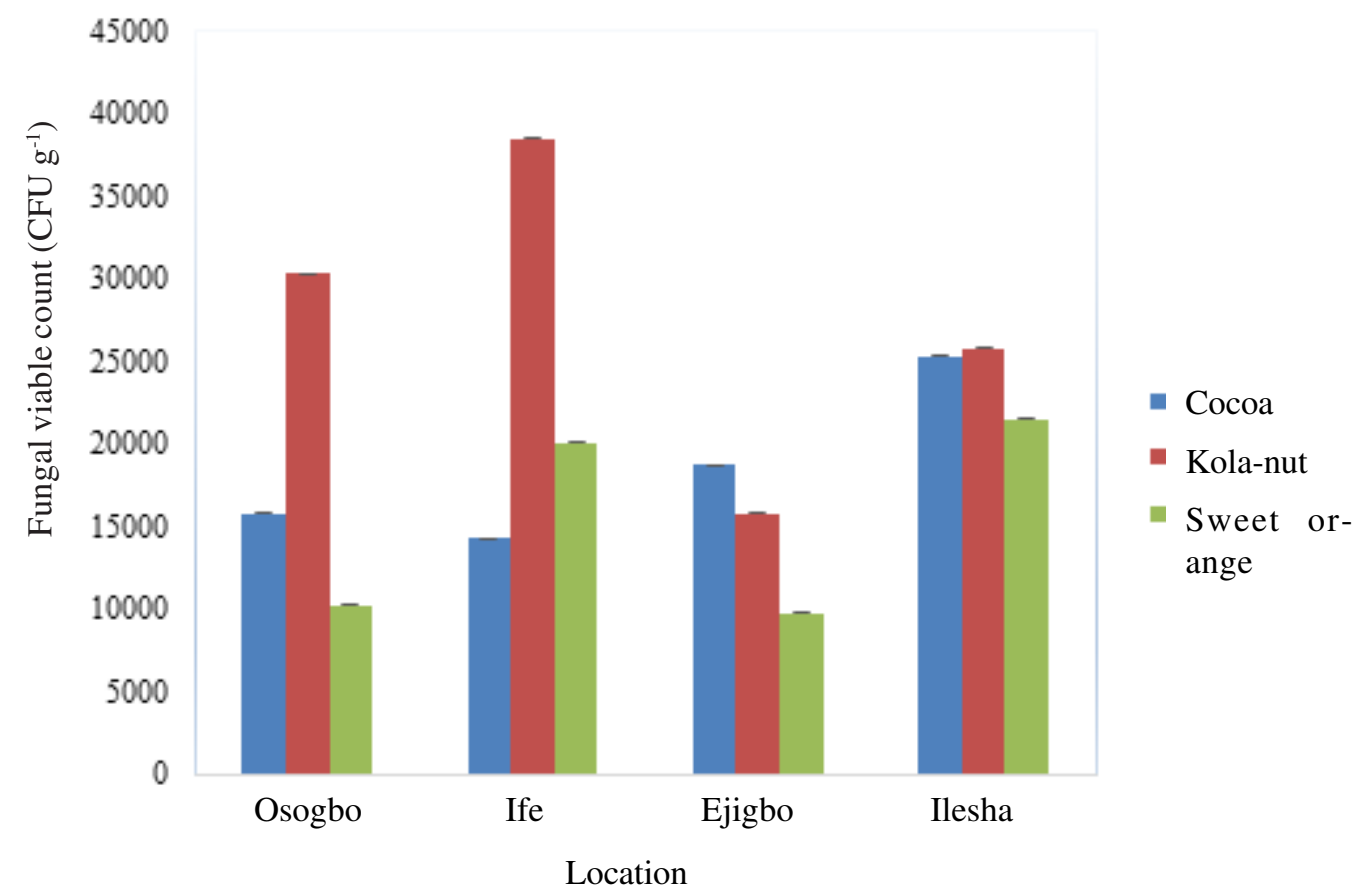

Figure 1. Mean viable fungal count in affected economic trees from different locations.

the whitish patch scrapings varied from one location to another; with Ilesha having the highest viable fungal count of $2.53 \times 10^{4} \pm$ $0.00 \mathrm{CFU} \mathrm{g}^{-1}$; and Ife having the lowest (1.43 $\left.\mathrm{x} 10^{4} \pm 0.01 \mathrm{CFU} \mathrm{g}^{-1}\right)$, particularly from the cocoa trees. The highest viable fungal count $\left(3.85 \times 10^{4} \pm 0.00 \mathrm{CFU} \mathrm{g}^{-1}\right)$ was observed in scrapings from kola-nut trees obtained from Ife; followed by Osogbo and Ilesha; Ejigbo had the lowest count $\left(1.58 \times 10^{4} \pm 0.01 \mathrm{CFU}\right.$ $\left.\mathrm{g}^{-1}\right)$. The viable fungal count in scrapings from sweet orange trees ranged between $9.75 \times 10^{3}$ $\pm 0.00 \mathrm{CFU} \mathrm{g}^{-1}$ and $2.15 \times 10^{4} \pm 0.00 \mathrm{CFU}$ $\mathrm{g}^{-1}$, with the highest coming from in Ilesha, and the lowest from Ejigbo site.

Results for the influence of location and tree type, and the interaction between the two on fungal distribution patterns among fruit tree types are presented in Tables $1-3$. There was a significant $(\mathrm{P}<0.05)$ difference between fungal counts in different crops and locations (Table 1). Fungal mean viable count of the affected trees was significantly influenced by location, but was highly significantly influenced by tree species and the interaction between the two.

There was no significant difference $(\mathrm{P}>$ 0.05 ) between viable counts for fungi in the three crop types across study sites (Table 2). No significant difference $(\mathrm{P}>0.05)$ also occurred between viable counts of fungi in cocoa and sweet orange. In contrast, kolanut, significantly more viable fungal counts than cocoa and sweet orange trees (Table 3).

A total of 52 fungal isolates were identified from the different locations and these comprised of 20 genera (Fig. 2). Aspergillus and Penicillium were the predominant fungal genera in all the samples.

Disaggregation of the fungal genera revealed up to 25 species in all the samples with 10,15 and 7 species occurring in the scrapings from cocoa, kola-nut and sweet orange trees, respectively (Table 4).

The highest fungal species diversity was noted in the samples obtained from kola-nut trees, followed by cocoa trees. The lowest 
TABLE 1. ANOVA table of viable fungal count in different economic trees and locations in south-west Nigeria

\begin{tabular}{llll}
\hline S/N & Variables & MS & P-value \\
\hline 1 & Block & $1.06 \times 10^{8, \text { ns }}$ & 0.1972 \\
2 & Location & $2.94 \times 10^{8, *}$ & 0.0058 \\
3 & Tree type & $9.62 \times 10^{8, * *}$ & 0.0000 \\
4 & Location õ tree & $3.11 \times 10^{8, * *}$ & 0.0004 \\
\hline
\end{tabular}

MS = Mean separation, ${ }^{\mathrm{ns}}=$ Non-significant, $*$ = significant, $* *=$ highly significant

TABLE 2. Mean fungal count of white patch samples for different locations in south-west Nigeria

\begin{tabular}{lll}
\hline S/N & Location & Mean viable count $\left(\mathrm{CFUg}^{-1}\right)$ \\
\hline 1 & Osogbo & $2.10 \times 10^{4 \mathrm{a}}$ \\
2 & Ife & $2.20 \times 10^{4 \mathrm{a}}$ \\
3 & Ejigbo & $1.48 \times 10^{4 \mathrm{~b}}$ \\
4 & Ilesha & $2.42 \times 10^{4 \mathrm{a}}$ \\
\hline
\end{tabular}

Mean values with the same superscript "a" are statistically comparable but significantly different from superscript " $b$ "

TABLE 3. Mean fungal count of white patch samples for different economic trees in south-west Nigeria

\begin{tabular}{llc}
\hline S/N. & Tree type & Mean viable count $\left(\mathrm{CFU} \mathrm{g}{ }^{-1}\right)$ \\
\hline 1 & Cocoa & $1.90 \times 10^{4 \mathrm{~b}}$ \\
2 & Kola-nut & $2.76 \times 10^{4 \mathrm{a}}$ \\
3 & Sweet orange & $1.54 \times 10^{4 \mathrm{~b}}$ \\
\hline
\end{tabular}

Mean values with the same superscript " $b$ " are statistically comparable but significantly different from superscript " $a$ "

fungal species diversity was observed from samples from sweet orange trees.

\section{DISCUSSION}

The dry scaly nature of the whitish patch lesions and the localised pattern of spread on the outer bark of the affected fruit trees (Plate
1) in the study plantations depicted possible fungal attack. In fact, high fungal densities were observed in the samples across locations (Fig. 1). The observed high fungal densities in the scraping samples of the affected tree parts could be attributed to the cultivation pattern (Asogwa et al., 2011), reliance on crop propagation from the wild varieties and low 


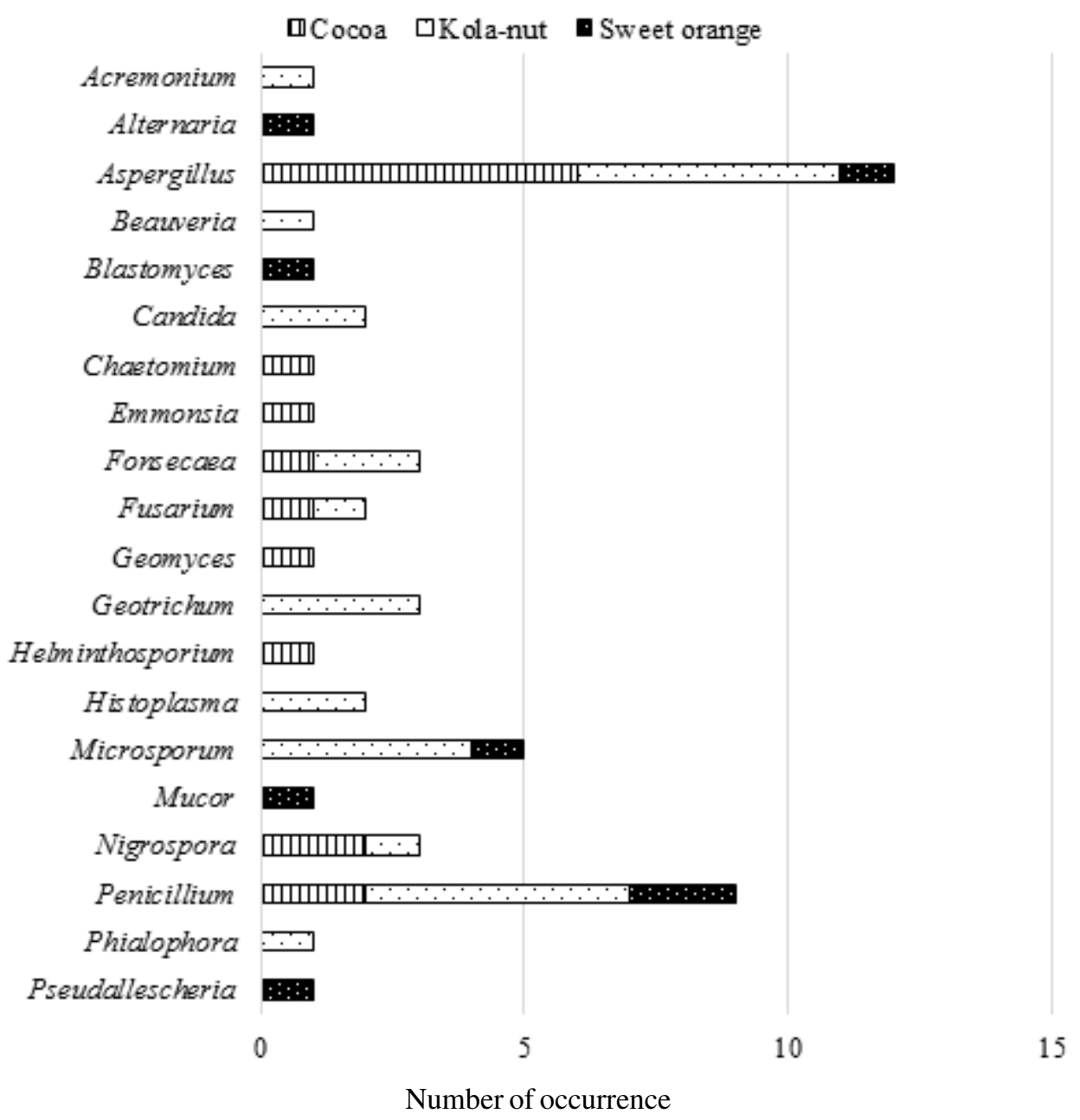

Figure 2. Fungal diversity of white patches from trunk of cocoa, kola-nut and sweet orange trees.

resistance to diseases as the plants age (Etebu and Nwauzoma, 2014; Bailey et al., 2016; Surujdeo-Maharaj et al., 2016).

The differences in fungal populations among various tree types at the different locations may be attributed to differences in environmental factors such as the local climatic conditions, e.g. wind, rainfall and relative humidity (Table 1). The comparatively lower fungal intensity observed in Ejigbo plantations than in Osogbo, Ife and Ilesha plantations (Table 2) could be attributed to the direction of movement of dust-laden wind, which blows from the Sahara Desert over West Africa, into the Gulf of Guinea (Oladele, 2007; Minka and
Ayo, 2014). Ejigbo is farther north of the other three locations.

In the present study, kola-nut trees harboured more fungal load in their whitish patch lesions compared to cocoa and sweet orange trees (Table 3). Fungal exposure to ineffective concentrations of the preformed antifungal compounds, delayed or lack of production of induced antifungal compounds, fungal resistance to the plant's defense mechanisms or combination of any of these might be responsible for the variation in fungal load (Morrissey and Osbourn, 1999; Dixon,2001; Santoso et al., 2017; Tiku, 2018). These fungal load could be found in the 
TABLE 4. Species distribution of fungi associated with white patches on the trunks of cocoa, kola-nut and sweet orange trees in south-west Nigeria

\begin{tabular}{|c|c|c|c|c|c|c|}
\hline \multirow[t]{2}{*}{ Sample location } & \multicolumn{2}{|c|}{ Cocoa } & \multicolumn{2}{|l|}{ Kola-nut } & \multicolumn{2}{|l|}{ Sweet orange } \\
\hline & Fungal species & $\begin{array}{c}\text { No. of } \\
\text { occurrence }\end{array}$ & Fungal species & $\begin{array}{l}\text { No. of } \\
\text { occurrence }\end{array}$ & Fungal species & $\begin{array}{l}\text { No. of } \\
\text { occurrence }\end{array}$ \\
\hline Osogbo & $\begin{array}{l}\text { Chaetomium globosum } \\
\text { Emmonsia crescens } \\
\text { Geomyces pannorum } \\
\text { Penicillium verrucosum }\end{array}$ & $\begin{array}{l}1 \\
1 \\
1 \\
1\end{array}$ & $\begin{array}{l}\text { Beauveria bassiana } \\
\text { Candida albicans } \\
\text { Candida parapsilosis } \\
\text { Histoplasma capsulatum } \\
\text { Microsporum audouinii } \\
\text { Microsporum nanum } \\
\text { Penicillium verrucosum }\end{array}$ & $\begin{array}{l}1 \\
1 \\
1 \\
1 \\
1 \\
1 \\
2\end{array}$ & Microsporum nanum & 1 \\
\hline Ife & $\begin{array}{l}\text { Aspergillus nidulans } \\
\text { Helminthosporium } \mathrm{sp} . \\
\text { Penicillium verrucosum }\end{array}$ & $\begin{array}{l}1 \\
1 \\
1\end{array}$ & $\begin{array}{l}\text { Aspergillus nidulans } \\
\text { Aspergillus niger } \\
\text { Geotrichum candidum } \\
\text { Penicillium verrucosum }\end{array}$ & $\begin{array}{l}1 \\
1 \\
1 \\
1\end{array}$ & $\begin{array}{l}\text { Mucor sp. } \\
\text { Penicillium verrucosum }\end{array}$ & $\begin{array}{l}1 \\
1\end{array}$ \\
\hline Ejigbo & $\begin{array}{l}\text { Aspergillus niger } \\
\text { Nigrospora sp. }\end{array}$ & $\begin{array}{l}4 \\
1\end{array}$ & $\begin{array}{l}\text { Acremonium murorum } \\
\text { Fonsecaea pedrosoi } \\
\text { Geotrichum candidum }\end{array}$ & $\begin{array}{l}1 \\
1 \\
1\end{array}$ & Pseudallescheria boydii & 1 \\
\hline Ilesha & $\begin{array}{l}\text { Aspergillus niger } \\
\text { Fonsecaea pedrosoi } \\
\text { Fusarium oxysporum } \\
\text { Nigrospora sp. }\end{array}$ & $\begin{array}{l}1 \\
1 \\
1 \\
1\end{array}$ & $\begin{array}{l}\text { Aspergillus niger } \\
\text { Fonsecaea pedrosoi } \\
\text { Fusarium oxysporum } \\
\text { Geotrichum candidum } \\
\text { Histoplasma capsulatum } \\
\text { Microsporum audouinii } \\
\text { Microsporum ferrugineum } \\
\text { Nigrospora sp. } \\
\text { Penicillium verrucosum } \\
\text { Phialophora verrucosa }\end{array}$ & $\begin{array}{l}3 \\
1 \\
1 \\
1 \\
1 \\
1 \\
1 \\
1 \\
2 \\
1\end{array}$ & $\begin{array}{l}\text { Alternaria alternata } \\
\text { Aspergillus niger } \\
\text { Blastomyces dermatitidis } \\
\text { Penicillium verrucosum }\end{array}$ & $\begin{array}{l}1 \\
1 \\
1 \\
1\end{array}$ \\
\hline
\end{tabular}


whitish patch samples from the affected kolanut, cocoa and sweet orange trees.

We noticed that there was absence of pods on the areas covered by the whitish patches on cocoa trees. The powdery nature of the whitish patches formed by the fungal mycelia had potential for prevention of the development of flowers from the affected spots on cocoa trees or cause permanent damage to the flower cushions (Chavez et al., 2010; ToledoHernández et al., 2017), thereby leading to drastic yield and economic losses (Fisher et al., 2012). In contrast, fungal presence appeared benign on the trunks and branches of kola-nut and sweet orange trees. Although the exact damage caused by these fungi to the affected kola-nut and sweet orange trees cannot be ascertained, due to lack of physical damage, unlike cocoa which show absence of pods on the affected parts, it might signal a reduction in the production of constitutive plant compounds with antifungal activity in the affected areas as part of the plant's aging process or nutrient deficiency (Minyaka et al., 2017; Pusztahelyi et al., 2017).

The predominance of Aspergillus and Penicillium among the general obtained from the samples (Fig. 2) from the study fruit trees, may be attributed to their fungi ability to produce spores that are resistant to various environmental stressors (Bukar et al., 2009). Besides, these two are filamentous fungi with autophagic mechanism for survival nutrientdeficient environment (Richie et al, 2007; Pollack et al., 2009; Bartoszewska et al., 2011).

Aspergillus niger and Penicillium verrucosum, unlike Phytophthora spp. (Mvondo et al., 2017) and Moniliophthora spp. (Patrocínio et al., 2017), which are established host-specific pathogens of woody plants, are generally found in a saprophytic or endophytic relationship with the plant hosts (Busby et al., 2016; Deng and Cao, 2017). Nevertheless, their phytopathogenic potential can manifest in plants with age-induced stress or nutrient deficiency condition (SánchezHervás et al., 2008; Bartoszewska et al.,
2011). Further investigations are required to understand the response of aged woody plants to microbial invasion. In the meantime, appropriate containment measures are required to prevent further spread into unaffected contiguous plantations.

Variability of the fungal communities in composition and structure in the samples from the three trees and across the four locations (Table 4) could be attributed to the fungal spore size and the degree of mycelial fragmentation; and subsequent aerosolisation (Adhikari et al., 2009; Gralton et al., 2011; Barberán et al., 2015; Spilak et al., 2015). Most of the isolated fungal species are important causative agents of postharvest diseases of cocoa, kola-nuts and citrus trees (Peever et al., 2005; Ezeibekwe et al., 2008; Singh et al., 2012; Anitha et al., 2014; Akinde et al., 2017). These key findings are noteworthy for improvement in sanitation and overall management of old plantations.

\section{ACKNOWLEDGEMENT}

The study was initiated and financed by the investigators based on the complaints from the affected farmers. All laboratory analyses were carried out in the Department of Microbiology, Osun State University, Osogbo, Nigeria.

\section{REFERENCES}

Adejumo, T.O. 2005. Crop protection strategies for major diseases of cocoa, coffee and cashew in Nigeria. African Journal of Biotechnology 4(2):143-150.

Adhikari, A., Jung, J., Reponen, T., Lewis, J.S., DeGrasse, E.C., Grimsley, L.F., Chew, G.L. and Grinshpun, S.A. 2009. Aerosolization of fungi, $(1 \rightarrow 3)-\beta$-d glucan, and endotoxin from flood-affected materials collected in New Orleans homes. Environmental Research 109(3):215-224.

Akinde, S.B., Adeniyi, M.A., Adebunmi, A.A., Oluwajide, O.O. and Ogunnaike, O.O. 2017. Comparative effectiveness of chemical biocides and Acalypha wilkesiana leaf extract against postharvest fungal 
deteriogens of sweet orange (Citrus sinensis) fruits. Egyptian Journal of Basic \& Applied Sciences 4(2):143-152.

Anitha, M., Swathy, S.R. and Venkateswari, P. 2014. Prevalence of disease-causing microorganisms in decaying fruits with analysis of fungal and bacterial species. International Journal of Research in Health Sciences 2(2):547-54.

Asogwa, E.U., Otuonye, A.H., Mokwunye, F.C., Oluyole, K.A., Ndubuaku, T.C.N. and Uwagboe, E.O. 2011. Kola-nut production, processing and marketing in the Southeastern states of Nigeria. African Journal of Plant Science 5(10):547-551.

Bailey, B.A., Ali, S.S., Akrofi, A.Y. and Meinhardt, L.W. 2016. Phytophthora megakarya, a causal agent of black pod rot in Africa. In: Cacao Diseases. Springer International Publishing. pp. 267-303.

Barberán, A., Ladau, J., Leff, J.W., Pollard, K.S., Menninger, H.L., Dunn, R.R. and Fierer, N. 2015. Continental-scale distributions of dust-associated bacteria and fungi. Proceedings of the National Academy of Sciences pp. 1-6.

Bartoszewska, M., Kiel, J.A., Bovenberg, R.A., Veenhuis, M. and van der Klei, I.J. 2011. Autophagy deficiency promotes $\beta$-lactam production in Penicillium chrysogenum. Applied \& Environmental Microbiology 77(4):1413-1422.

Bukar, A., Mukhtar, M.D. and Adamu, S. 2009. Isolation and identification of postharvest spoilage fungi associated with sweet oranges (Citrus sinensis) traded in Kano metropolis. Bayero Journal of Pure \& Applied Sciences 2(1):122-124.

Busby, P.E., Ridout, M. and Newcombe, G. 2016. Fungal endophytes: modifiers of plant disease. Plant Molecular Biology 90(6):645-655.

Campbell, C.K. and Johnson, E.M. 2013. Identification of pathogenic fungi. $2^{\text {nd }}$ Edition, John Wiley and Sons. 350pp.

Chavez, N., Bustillos, R.C., Domian, C.A., Chaverri, F.Q., Morales, N.V. and Aguilar,
L.O. 2010. Sexual reproduction of Cacao. CATIE Materiales de Extension (1).

Deng, Z. and Cao, L. 2017. Fungal endophytes and their interactions with plants in phytoremediation: a review. Chemosphere 168:1100-1106.

Dixon, R.A. 2001. Natural products and plant disease resistance. Nature 411(6839):843.

Etebu, E. and Nwauzoma, A.B. 2014. A review on sweet orange (Citrus sinensis L Osbeck): Health, diseases and management. American Journal of Research Communication 2(2):33-70.

Ezeibekwe, I.O., Onuoha, C.I., Mbagwu, F.N. and Nwachukwu, P.C. 2008. Studies on soil pathogen associated with citrus disease. International Science Research Journal 1(2):165-168.

Fallico, B., Ballistreri, G., Arena, E., Brighina, S. and Rapisarda, P. 2017. Bioactive compounds in blood oranges (Citrus sinensis (L.) Osbeck): Level and intake. Food Chemistry 215:67-75.

Fisher, M.C., Henk, D.A., Briggs, C.J., Brownstein, J.S., Madoff, L.C., McCraw, S.L. and Gurr, S.J. 2012. Emerging fungal threats to animal, plant and ecosystem health. Nature 484:186-194.

Gralton, J., Tovey, E., McLaws, M.L. and Rawlinson, W.D. 2011. The role of particle size in aerosolised pathogen transmission: a review. Journal of Infection 62(1):1-13.

Humber, R.A. 1997. Fungi identiûcation: Manual of techniques in insect pathology. Academic, San Diego, CA. pp. 153-185.

Mejía, L.C., Herre, E.A., Sparks, J.P., Winter, K., García, M.N., Van Bael, S.A., Stitt, J., Shi, Z., Zhang, Y., Guiltinan, M.J. and Maximova, S.N. 2014. Pervasive effects of a dominant foliar endophytic fungus on host genetic and phenotypic expression in a tropical tree. Frontiers in Microbiology 5(479):1-16.

Minka, N.S. and Ayo, J.O. 2014. Influence of cold-dry (harmattan) season on colonic temperature and the development of pulmonary hypertension in broiler chickens, 
and the modulating effect of ascorbic acid. Open Access Animal Physiology 6:1-11.

Minyaka, E., Simo, C., Kusznierewicz, B., Madina, B., Mouen, P., Niemenak, N. and Omokolo, N. 2017. Flavones in cocoa defence against Phytophthora megakarya. Research \& Reviews: Journal of Botanical Sciences 6(3):50-63.

Morrissey, J.P. and Osbourn, A.E. 1999. Fungal resistance to plant antibiotics as a mechanism of pathogenesis. Microbiology \& Molecular Biology Reviews 63(3):708724.

Mvondo, E.A., Ndo, E.G.D., Bieng, M.A.N., Ambang, Z., Manga, B., Cilas, C., Manga, M.L.T. and Nomo, L.B. 2017. Assessment of the interaction between the spatial organization of citrus trees populations in cocoa agroforests and Phytophthora foot rot disease of citrus severity. Agroforestry Systems. pp. 1-10.

Nwachukwu, S.C.U. and Akpata, T.V.I. 2003. Isolation of microorganisms by spread plate technique. In: Principles of quantitative microbiology. University of Lagos Press. pp. 3-6.

Oboh, G., Akinyemi, A.J., Omojokun, O.S. and Oyeleye, I.S. 2014a. Anticholinesterase and antioxidative properties of aqueous extract of Cola acuminata seed in vitro. International Journal of Alzheimer's Disease 2014:1-8.

Oboh, G., Nwokocha, K.E., Akinyemi, A.J. and Ademiluyi, A.O. 2014b. Inhibitory effect of polyphenolic-rich extract from Cola nitida (Kola-nut) seed on key enzyme linked to type 2 diabetes and $\mathrm{Fe}^{2+}$ induced lipid peroxidation in rat pancreas in-vitro. Asian Pacific Journal of Tropical Biomedicine 4:S405-S412.

Oladele AO. 2007. Harmattan haze and environmental health. African Journal of Environmental Science \& Technology 1(4):1-3.

Patrocínio, N.G.R.B., Ceresini, P.C., Gomes, L.I.S., Resende, M.L.V., Mizubuti, E.S.G. and Gramacho, K.P. 2017. Population structure and migration of the witches' broom pathogen Moniliophthora perniciosa from cacao and cultivated and wild solanaceous hosts in southeastern Brazil. Plant Pathology 66(6):900-911.

Peever, T.L., Carpenter-Boggs, L., Timmer, L.W., Carris, L.M. and Bhatia, A. 2005. Citrus black rot is caused by phylogenetically distinct lineages of Alternaria alternata. Phytopathology 95(5):512-518.

Ploetz, R. 2016. The impact of diseases on cacao production: a global overview. In Cacao diseases. Springer, Cham. pp. 3359.

Pollack, J.K., Harris, S.D. and Marten, M.R. 2009. Autophagy in filamentous fungi. Fungal Genetics \& Biology 46:1-8.

Pusztahelyi, T., Holb, I.J. and Pócsi, I. 2017. Plant-fungal interactions: Special secondary metabolites of the biotrophic, necrotrophic, and other specific interactions. Fungal Metabolites. pp. 1-58.

Richie, D.L., Fuller, K.K., Fortwendel, J., Miley, M.D., McCarthy, J.W., Feldmesser, M., Rhodes, J.C. and Askew, D.S. 2007. Unexpected link between metal ion deficiency and autophagy in Aspergillus fumigatus. Eukaryotic Cell 6(12):24372447.

Sánchez-Hervás, M., Gil, J.V., Bisbal, F., Ramón, D. and Martínez-Culebras, P.V. 2008. Mycobiota and mycotoxin producing fungi from cocoa beans. International Journal of Food Microbiology 125(3):336340.

Santoso, T.I., Miftahudin, M., Sulistyaningsih, Y.C. and Wiyono, S. 2017. Analysis of Secondary Metabolites as Potential Phytoalexins, Their Secretion Sites and Proposed Resistance Markers to Vascular Streak Dieback in Theobroma cacao L.Pelita Perkebunan (a Coffee and Cocoa Research Journal) 33(1):10-23.

Singh, H., Al-samarai, G. and Syarhabil, M. 2012. Exploitation of natural products as an alternative strategy to control 
postharvest fungal rotting of citrus. International Journal of Scientific \& Research Publications 2(3): 1-4.

Spilak, M.P., Madsen, A.M., Knudsen, S.M., Kolarik, B., Hansen, E.W., Frederiksen, M. and Gunnarsen, L. 2015. Impact of dwelling characteristics on concentrations of bacteria, fungi, endotoxin and total inflammatory potential in settled dust. Building \& Environment 93:64-71.

Surujdeo-Maharaj, S., Sreenivasan, T.N., Motilal, L.A. and Umaharan, P. 2016. Black pod and other phytophthora induced diseases of cacao: History, biology, and control. In: Cacao Diseases. Springer International Publishing. pp. 213-266.

Teixeira, P.J., de Toledo Thomazella, D.P., Reis, O., Do Prado, P.F., Do Rio, M.C., Fiorin, G.L., José, J., Costa, G.G., Negri, V.A., Mondego, J.M. and Mieczkowski, P. 2014. High-resolution transcript profiling of the atypical biotrophic interaction between Theobroma cacao and the fungal pathogen Moniliophthora perniciosa. The Plant Cell 26(11):4245-4269.

Tiku, A.R. 2018. Antimicrobial Compounds and Their Role in Plant Defence. In Molecular Aspects of Plant-Pathogen Interaction. Springer, Singapore. pp. 283307.

Toledo-Hernández, M., Wanger, T.C. and Tscharntke, T. 2017. Neglected pollinators: Can enhanced pollination services improve cocoa yields? A review. Agriculture, Ecosystems \& Environment 247:137-148.

Verter, N. and Beèváøová, V. 2014. Analysis of some drivers of cocoa export in Nigeria in the era of trade liberalization. Agris online Papers in Economics and Informatics 6(4):208.

Verter, N. and Beèváøová, V. 2016. The impact of agricultural exports on economic growth in Nigeria. Acta Universitatis Agriculturae et Silviculturae Mendelianae Brunensis 64(2):691-700. 